Editorial

\section{Medical professionalism and ideological symbols in doctors' rooms} Udo Schuklenk

Is it time to leave the non-professional aspects of personal life at the door and face patients as medical professionals and no more?

$\mathrm{E}$ er wondered about the appropriateness of Christian doctors displaying pictures of Pope Benedict, Muslim doctors displaying pictures of Osama son of Laden or former PLO leader Yassir Arafat, or gay doctors proudly flying the rainbow flag in their rooms? I suggest that we should be concerned about such display of religious, political, or other allegiance to non-professional causes in loci of health care delivery.

Let us take a step back, however, and ask why we seek health care professionals' help or assistance. Our reasons have, of course, primarily to do with doing our fair share by way of enabling health care delivery services to achieve their primary objectives for being in existence, namely to ensure that we live as long as is feasible at as high a quality of life as is possible. While legitimate questions may be asked about acceptable trade-offs between length and quality of life, broadly speaking, that is what we expect health care providers to do for us. Importantly, we expect them to do so in a professional manner. This is very much in line with the historical roots of the idea of professionalism, meaning essentially to profess publicly to serve the public good. ${ }^{1}$ The public interest (if we understand it in the health care arena as the aggregated form of satisfied/frustrated individual health related interests) is well served by doctors improving individual patients' health and well-being.

One of the uncontroversial hallmarks of professionalism is that it requires the professional to act in an impartial, unbiased manner. ${ }^{2}$ This, arguably gives us the first clue as to why health care professionals should refrain from displaying symbols in their offices advising patients of the professionals' private lives' religious, party political, sexual, or other affiliations. It is common knowledge that one of the central features of the doctorpatient relationship is trust. Patients' trust in their doctors' professional integrity and impartiality is a necessary condition for honest disclosure of, for instance, embarrassing and potentially compromising information a patient might need to disclose during the consultation. Say, if in today's South Africa a patient should disclose unsafe sexual encounters with various people whose HIV status is unknown to him or her in order to assist a prudent risk-assessment and diagnosis, clearly the display of religious symbols in the consultation room is likely to prevent full and frank disclosure. After all, both Islam and Christianity tend to frown upon sexual behaviour outside the marital context. If a doctor displays these ideologies' symbols in her rooms, patients have reason to be reluctant to disclose what they have actually done, in order to avoid a potential moral judgment by the doctor. As a foreseeable consequence the primary objectives of health care are defeated by a narrow non-professional desire of the doctor to let patients know about an entirely private matter, namely his or her religious preferences. It goes without saying that health care professionals, like everyone else are entitled to display their religious affiliations publicly in their private capacities, outside working hours.

Women in need of professional advice regarding pregnancy testing, abortion, and birth control have reason to be reluctant to disclose relevant information to doctors displaying paraphernalia of religions critical of birth control (such as, for instance, Catholicism). Of course, a professional would not allow her personal preferences to interfere with any advice rendered, but confronting patients with information about these preferences in the consultation room is likely to interfere negatively with the place between the health care professional and the patient.

Similarly, gays and lesbians are known to be reluctant to see doctors due to concerns about these professionals' responses to their sexual orientation. ${ }^{3}$ Some of these concerns seem confirmed by reported real-world experiences of such patients when visiting health care professionals. This has demonstrably negative consequences for the well-being of these discriminated against patients. interrogation and conversation taking
Suboptimal health outcomes are produced because of doctors' unprofessional response to patients. Part of the unprofessional response, no doubt, is the display of religious or other symbols in doctors' rooms that are likely to interfere negatively with the dialogue between doctor and patient. Doctors displaying such symbols in their rooms should consider removing them. Arguably a similar point can be made with regard to teachers in health sciences faculties displaying such symbols.

People wearing skullcaps or purdah, presumably do so, not merely to identify themselves as followers of a particular faith, but also because their belief system might demand it. The question remains how to deal with this in a professional context. We are clearly confronted here with a clash between the individual interests of the wearer of the symbolic dress, and the demands of professional impartiality. The wearer will argue that her religious beliefs and the visual symbols do not hinder her professional treatment of the patient. This may well be true, but that is not the point. The issue at hand is how the patient perceives and interprets the symbols and the negative consequences of with-holding vital lifestyle or health-related information for fear of disapprobation from the doctor or other health care professionals. While it might not be logical for the patient to assume, based on the doctor's dress, that he or she is a strong adherent of the religion, if they choose to dress in a particular way, it is understandable that many patients would do just that. Given that many people practice religion without adopting a particular dress form, it is not an unreasonable assumption that those who adopt the dress form are particularly rigorous about their faith and its tenets. This must act as an even greater deterrent to full disclosure from the patient than pictures and religious jewellery. In this case, the religious symbology goes beyond a picture on the wall. The doctor is in effect saying to all, that he has literally clothed himself in his faith - this is who he is and what he believes. It would take an intrepid patient to face this doctor and disclose-for example, a drug addiction. It would be nearly impossible for a young adolescent, confused about her sexuality to discuss this with a doctor who is clothed in the raiments of religion. Perhaps it is time to leave the nonprofessional aspects of personal life at the door and face patients as medical professionals and no more.

\section{ACKNOWLEDGEMENTS}

I am very grateful to Anita Kleinsmidt and the Editors of this journal for constructive criticism of earlier versions of this paper. 
J Med Ethics 2006;32:1-2.

doi: 10.1136/jme.2005.014373

Correspondence to: U Schuklenk, Centre for Ethics in Public Policy and Corporate Governance, Glasgow Caledonian University, Glasgow, UK; udo.schuklenk@gmail.com
Received 8 September 2005

Accepted for publication 19 September 2005

\section{REFERENCES}

1 Koehn D. The Ground of Professional Ethics. London: Routledge, 1994.
2 Emanuel E, Emanuel L. 4 models of the physicianpatient relationship. In: Arras J, Steinbock B, eds. Ethical Issues in Modern Medicine. Westview: Mayfield Publishing, 1997.

3 Harrison A. Primary Care of Lesbian \& Gay Patients: Educating Ourselves and Our Students in Family. Medicine Family Medicine 1996;28:10-20.

\section{Clinical Evidence-Call for contributors}

Clinical Evidence is a regularly updated evidence-based journal available worldwide both as a paper version and on the internet. Clinical Evidence needs to recruit a number of new contributors. Contributors are healthcare professionals or epidemiologists with experience in evidence-based medicine and the ability to write in a concise and structured way.

Areas for which we are currently seeking contributors:

- Pregnancy and childbirth

- Endocrine disorders

- Palliative care

- Tropical diseases

We are also looking for contributors for existing topics. For full details on what these topics are please visit www.clinicalevidence.com/ceweb/contribute/index.jsp

However, we are always looking for others, so do not let this list discourage you.

Being a contributor involves:

- Selecting from a validated, screened search (performed by in-house Information Specialists) epidemiologically sound studies for inclusion.

- Documenting your decisions about which studies to include on an inclusion and exclusion form, which we keep on file.

- Writing the text to a highly structured template (about 1500-3000 words), using evidence from the final studies chosen, within 8-10 weeks of receiving the literature search.

- Working with Clinical Evidence editors to ensure that the final text meets epidemiological and style standards.

- Updating the text every 12 months using any new, sound evidence that becomes available. The Clinical Evidence in-house team will conduct the searches for contributors; your task is simply to filter out high quality studies and incorporate them in the existing text.

If you would like to become a contributor for Clinical Evidence or require more information about what this involves please send your contact details and a copy of your CV, clearly stating the clinical area you are interested in, to CECommissioning@bmigroup.com.

\section{Call for peer reviewers}

Clinical Evidence also needs to recruit a number of new peer reviewers specifically with an interest in the clinical areas stated above, and also others related to general practice. Peer reviewers are healthcare professionals or epidemiologists with experience in evidence-based medicine. As a peer reviewer you would be asked for your views on the clinical relevance, validity, and accessibility of specific topics within the journal, and their usefulness to the intended audience (international generalists and healthcare professionals, possibly with limited statistical knowledge). Topics are usually 1500-3000 words in length and we would ask you to review between 2-5 topics per year. The peer review process takes place throughout the year, and out turnaround time for each review is ideally 10-14 days.

If you are interested in becoming a peer reviewer for Clinical Evidence, please complete the peer review questionnaire at www. clinicalevidence.com/ceweb/contribute/peerreviewer.jsp 